\title{
Small size in the common bottlenose dolphin Tursiops truncatus in the eastern Mediterranean: a possible case of Levantine nanism
}

\author{
Yuli Sharir ${ }^{1, *}$, Dan Kerem ${ }^{1}$, Pavel Gol'din² ${ }^{2}$ Ehud Spanier ${ }^{1}$ \\ ${ }^{1}$ The Leon Recanati Institute for Maritime Studies and the Department of Maritime Civilizations, \\ the Leon H. Charney School for Marine Sciences, University of Haifa, Mount Carmel, Haifa 31905, Israel \\ ${ }^{2}$ Department of Zoology, V.I. Vernadsky Taurida National University, Simferopol, Crimea 95007, Ukraine
}

\begin{abstract}
The phenomenon of Levantine nanism in the Mediterranean Sea has so far been described in invertebrates and fish. We explored the possibility that it would also apply to marine mammals. To that end, we compared total body length (TBL) and skull condylobasal length (CBL) of adult common bottlenose dolphins Tursiops truncatus collected along the Israeli coastline (representing the Levantine subpopulation) to those of specimens collected along the shores of western Mediterranean seas. Significant differences were found between mean $( \pm$ SD) CBL values of 40 skulls from Israel and a pooled sample of 40 skulls from the Adriatic, Tyrrhenian, Ligurian and Balearic Seas $(49.70 \pm 1.87$ and $52.18 \pm 1.47 \mathrm{~cm}$, respectively, $\mathrm{p}<0.001)$. The mean $( \pm \mathrm{SD}) \mathrm{TBL}$ of 26 Israeli animals were significantly smaller than those of 28 animals from the Spanish Mediterranean coast and 36 animals from the French Mediterranean coast $(272 \pm 18.0,317.3 \pm 16.1$ and $313.4 \pm 14.8 \mathrm{~cm}$, respectively, $\mathrm{p}<0.001$ ). The results clearly demonstrate that animals of the Levantine subpopulation are significantly smaller than those residing in the west. A difference of $\sim 16 \%$ for TBL between populations fits the range of within-species dwarf morphs in cetaceans and, when translated into volume and mass, also fits the definition of Levantine nanism.
\end{abstract}

KEY WORDS: Dwarfism $\cdot$ Craniometry $\cdot$ Mediterranean Sea $\cdot$ Marine mammals

\section{INTRODUCTION}

The Mediterranean is a semi-enclosed sea, almost isolated from the Atlantic Ocean, and is conventionally divided into 2 seas, western and eastern. The eastern Mediterranean and especially its easternmost portion, the Levantine Basin, are characterized by higher temperature and salinity, and by extreme oligotrophy (Dugdale \& Wilkerson 1988, Yacobi et al. 1995, Herut et al. 2000). These characteristics are caused by the scant river runoff and pronounced stratification, and are sustained by the unusual flow pattern at the Straits of Sicily (surface, nutrient-depleted water flows in, whereas intermediate and deep water with enhanced nutrient content flows out) (Krom et al. 2004).

Por (1989) coined the term 'Levantine nanism' to describe the phenomenon of representatives of many marine taxa having smaller body sizes (dwarfism) in the Levantine Basin. He suggested that such nanism might be the result of any one or the combination of exceptional environmental factors such as high salinity, high temperature and low productivity. Levantine nanism had been suggested for poikilotherms of various invertebrate and vertebrate taxonomic groups: sponges (Levi 1957), sipunculids (Stephen 1958), polychaetes (Laubier 1966), and deepwater bony fish (Tortonese 1960), and has recently been demonstrated quantitatively in red mullet Mullus barbatus (Sonin et al. 2007). Within-species dwarfism in cetaceans is restricted to subspecies or populations which possess smaller dimensions and usually maintain body proportions of the standard form, such as the dwarf spinner dolphin Stenella longirostris roseiventris from the Gulf of Thailand (Perrin et al. 1999), the dwarf common minke whale Balaenoptera acutorostrata subsp. in the Southern Hemisphere 
(Best 1985) and the dwarf killer whale Orcinus orca in the Antarctic (Berzin \& Vladimirov 1983, Rice 1998, Pitman et al. 2007). There is no clear geographical-cline basis for this distinction, as the dwarf and the regular morphs are often sympatric.

The common bottlenose dolphin (BD) Tursiops truncatus (Montagu, 1821) has a world-wide coastal distribution in tropical and temperate waters, including the Mediterranean Sea, the Black Sea, and the Red Sea (Leatherwood \& Reeves 1983, Kurihara \& Oda 2006). The species is very polymorphic, being characterized by variable body size, coloration and skull morphology, according to nutritional traits and geographic distribution (Turner \& Worthy 2003). The older literature describes specimens from the Northeast Atlantic and the Northwest Pacific BD populations as being much larger than those of the Mediterranean and the Black Sea populations, the latter comprising the smallest specimens (BarabashNikiforov 1940). This was reaffirmed in a recent craniometric study by Viaud-Martinez et al. (2008), who found mean skull condylobasal lengths (CBL) of $452.3 \mathrm{~mm}$ (Black Sea), $520.3 \mathrm{~mm}$ (Mediterranean, predominantly from the western basin) and $537.4 \mathrm{~mm}$ (Atlantic, Gulf of Lion). Additionally, in regions such as the Northwest Atlantic, 2 distinct morphs are described, one coastal and the other deep-sea, based on differences in hemoglobin content, skull morphology, external body measurements and proportions; in general, the deep-sea morph was described as having a more robust appearance (Hersh \& Duffield 1990). With this extent of global size variability, dwarfism in BD would have little meaning; however, the Mediterranean population of bottlenose dolphins may still conform to the phenomenon of Levantine nanism. Carrying capacity for top predators in the Levantine Basin is suspected of being intrinsically low, in line with the low primary productivity. In addition, over the last 2 decades a continuous decline of catch per unit effort by the stable-sized Israeli trawler fleet suggests over-fishing along the Israel coastline (Edelist et al. 2011). The combination of the 2 factors causes a regional reduction in food availability to bottlenose dolphins, which may be translated into fewer individuals (Bearzi et al. 1999, 2006) and/or to individuals reaching a smaller final adult size. The latter could provide a theoretical basis for an east-west size gradient.

Our study aims to broaden the concept of Levantine nanism to include a marine mammal, by determining whether dwarfism occurs in Israeli BD, while taking into account confounding factors such as thermoregulation that may apply to homeotherms.

\section{MATERIALS AND METHODS}

\section{General}

The preferred measure for size comparison is adult body mass of live healthy animals, taking into account seasonal variations, but this measure is only rarely available in cetaceans, e.g. in a long-range study of BD in Sarasota, Florida (Scott et al. 1990). Conversely, while total body length (TBL; snout-toanus) in land mammals suffers from inter- and even intra-measurer variability (mainly caused by the flexibility of the animals' spinal column), it is a good alternative measure to body mass in cetaceans, in which fused cervical vertebrae, lack of hind limbs, rigid tail and the flattening effect of the beach, dissection table or any flat surface on their body decrease measurement variability. However, since many stranded cetaceans are already in various states of decomposition or mummification when examined, reliable measurements are not possible. Skulls are considered to be the best-preserved remains from a beached marine mammal (Liebig et al. 2003) and the only one routinely kept in museums and academic collections, and accessible to scientists. Skulls are widely used in comparative studies of size in land mammals, their CBL being highly correlated to mass in diverse species (Ellison et al. 1993, Quin et al. 1996, Jones 1997, Meiri et al. 2004). Skulls have also provided the data for many morphometric studies in dolphins, using CBL as well as other craniometric measures to differentiate subspecies and geographic populations (Walker 1981, Mead \& Potter 1990, Kemper 2004, Viaud-Martinez et al. 2008). However, the assumption that skull size decreases proportionally to TBL cannot be taken for granted and needs verification, since e.g. the pygmy blue whale Balaenoptera musculus brevicauda from the Indian Ocean has a tail that is shorter relative to that of the blue whale B. musculus (Gilpatrick \& Perryman 2008) and the small BD from the Black Sea has a relatively larger head (Viaud-Martinez et al. 2008). Therefore, we have used TBL as an indicator of size whenever available and supplemented it with CBL measured on dolphins collected along the coast of Israel and of several western Mediterranean seas.

\section{Database}

TBL, measured as a straight line from the tip of the rostrum to the deepest part of the fluke notch (Norris 1961), was available for 105 beached or by-caught BDs 
of both sexes attended by The Israel Marine Mammal Research \& Assistance Center between 2000 and 2010. This set was compared to 2 TBL datasets from the French (142 specimens) and from the Spanish (109 specimens) Mediterranean coasts, contributed by Groupe d'Etude des Cétacés de Méditerranée (Marseille) and the University of Valencia, respectively, through the services of MEDACES (Mediterranean Database of Cetacean Strandings). There was no age information available for the latter 2 series,

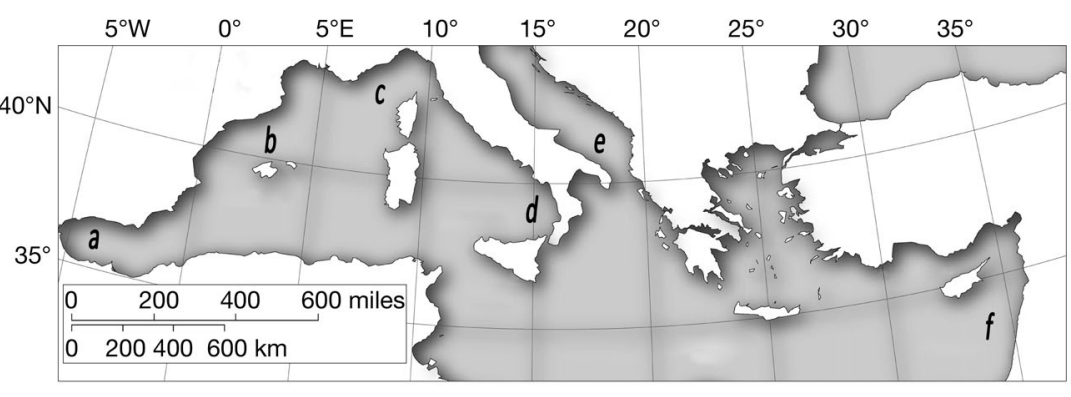

Fig. 1. Tursiops truncatus. Map of the Mediterranean seas and basins from where skulls of common bottlenose dolphins originated: (a) Alboran Sea ( $\mathrm{n}=$ 2), (b) Balearic Sea $(\mathrm{n}=4),(\mathrm{c})$ Ligurian Sea $(\mathrm{n}=3),(\mathrm{d})$ Tyrrhenian Sea $(\mathrm{n}=10)$, (e) Adriatic Sea $(n=19)$, (f) Levantine Basin (Israeli coast) $(n=40)$ therefore the mean lengths of the upper quartile from each set were compared, on the assumption that it mainly consisted of adult animals.

In total, 83 cranially mature skulls were available for comparison (maturity determined based on degree of fusion of maxillary and premaxillary bones; Dailey \& Perrin 1973, Perrin 1984, Leatherwood \& Reeves 1990, Mead \& Potter 1990, Perrin \& Heyning 1993). They belonged to museum collections across the Mediterranean: 42 from Israel (17 of them with TBL data) and 40 from the western basin (16 of them with TBL data) (Table 1, Fig. 1). The subsample of the western population skulls for which TBL was also known was predominantly (13 out of 16 ) from the Adriatic Sea. Two animals of either Adriatic or Tyrrhenian Sea origin were only included in pooled western versus eastern Mediterranean comparisons. All CBL measurements were obtained by Y.S. with a pair of compasses (60 $\mathrm{cm}$ long), to the nearest $1 \mathrm{~mm}$. Age of 18 specimens in the Israeli sample was estimated by P.G. from dentinal layer counts.

Table 1. Tursiops truncatus. Sources, gender and sample size of skull specimens of common bottlenose dolphins. $\mathrm{F}=$ female, $\mathrm{M}=$ male, ? = unknown sex

\begin{tabular}{|c|c|c|c|c|c|}
\hline Country & Collection & $\mathrm{F}$ & M & $?$ & Total \\
\hline \multirow[t]{5}{*}{ Israel } & University of Haifa (IMMRAC), Haifa & 5 & 11 & 9 & 25 \\
\hline & Haifa Zoo, Haifa & - & - & 2 & 2 \\
\hline & Tel Aviv University, Tel-Aviv & 5 & 1 & 8 & 14 \\
\hline & Oranim College, Tiv'on & - & - & 1 & 1 \\
\hline & Beit Dagan collection, Beit Dagan & - & - & 1 & 1 \\
\hline \multirow[t]{4}{*}{ Italy } & Zoological Museum, Rome & 1 & 4 & 3 & 8 \\
\hline & La Specola Zoological Museum, Florence & 1 & 2 & 2 & 5 \\
\hline & Fondazione Cetacea Onlus, Riccione & 4 & 7 & 2 & 13 \\
\hline & Museum of Natural History, Milan & 2 & 3 & 3 & 8 \\
\hline \multirow[t]{3}{*}{ Spain } & Zoological Museum, Barcelona & - & 1 & 1 & 2 \\
\hline & $\begin{array}{l}\text { University of Valencia (Evolutionary Biology), } \\
\text { Valencia }\end{array}$ & 2 & - & 1 & 3 \\
\hline & Doñana Biological Station (CSIC), Seville & - & - & 1 & 1 \\
\hline Total & & 20 & 29 & 34 & 83 \\
\hline
\end{tabular}

\section{Data analysis}

Following normality tests (Kolmogorov-Smirnov) and tests for homogeneity of variances (Levene), unpaired $t$-tests and ANOVA, or 2-sample and $k$ sample nonparametric tests, were used to compare group means or medians, respectively. Univariate and bivariate ANOVA were used to model gender and region effects on CBL and TBL. All analyses were performed using SPSS v.13.

\section{RESULTS}

\section{Age at cranial maturity}

Maturity of the skull as implied by rostral fusion was detected in all animals $\geq 4$ yr old in the Israeli sample. All animals aged $\leq 3$ yr were cranially immature; in one of them, a 3 yr old male, the rostrum was partly fused on both sides, but only over short sections.

\section{CBL-TBL correlation}

Based on a linear regression, skull length was significantly correlated to body length in a pooled east-west sample (the latter predominantly from the Adriatic Sea), for which both parameters were known $(\mathrm{p}=$ 0.0005), although the correlation was not strong (Fig. 2). In a subsample for which gender was also known (15 dolphins from Israel and 13 from the Italian coast of the Adriatic), a univariate ANOVA with CBL as the 


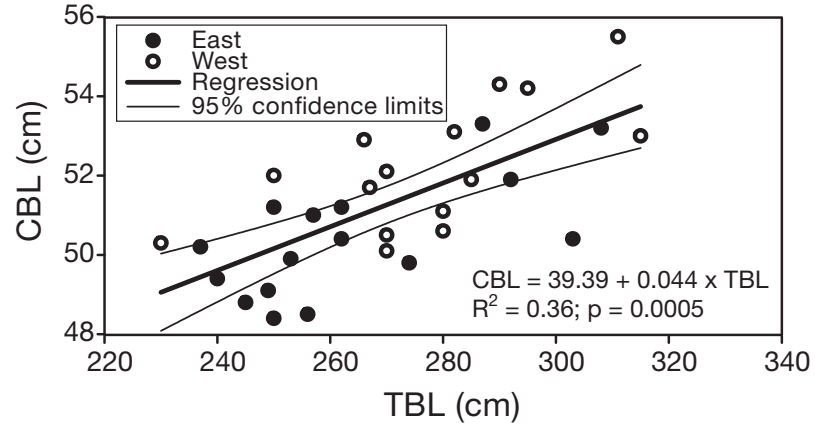

Fig. 2. Tursiops truncatus. Skull condylobasal length (CBL) versus total body length (TBL) of pooled Israeli (east) and western Mediterranean common bottlenose dolphin samples

Table 2. Tursiops truncatus. Results of a fitted univariate ANOVA testing the effects of total body length (TBL), region (Spain, France and Israel) and gender on condylobasal length of common bottlenose dolphins

\begin{tabular}{|lrrrr|}
\hline Source & $\begin{array}{c}\text { Sum of } \\
\text { squares }\end{array}$ & $\begin{array}{c}\text { Estimated } \\
\text { parameter }\end{array}$ & $F$ & $\mathrm{p}$ \\
\hline Corrected model & $60.521^{\mathrm{a}}$ & & 12.202 & $<0.001$ \\
Intercept & 405.149 & 42.18 & 245.063 & $<0.001$ \\
TBL & 25.869 & 0.39 & 15.647 & 0.001 \\
Region & 17.423 & -1.65 & 10.539 & 0.003 \\
Gender & 0.856 & -0.36 & 0.518 & 0.479 \\
Error & 39.678 & & & \\
${ }^{\mathrm{a}} \mathrm{R}^{2}=0.604$; adjusted $\mathrm{R}^{2}=0.555$ & & & \\
\hline
\end{tabular}

Table 3. Tursiops truncatus. Total body length (TBL; median) in the upper quartile groups of 3 common bottlenose dolphin populations

\begin{tabular}{|lccc|}
\hline Population & $\mathrm{N}$ & TBL $(\mathrm{cm})$ & Range \\
\hline Israel & 26 & 265 & $253-310$ \\
France & 36 & 310 & $300-360$ \\
Spain & 27 & 317 & $296-350$ \\
\hline
\end{tabular}

dependent variable indicated significant effects of TBL and region but not of gender (Table 2). Analysis of covariance did not reveal a significant interaction between TBL and region. Bivariate ANOVA, with both CBL and TBL as dependent variables, showed that neither gender nor region had a significant effect on the 2 length measures.

\section{Sexual dimorphism}

Gender-dependent differences in body lengths and skull lengths were further evaluated in datasets not

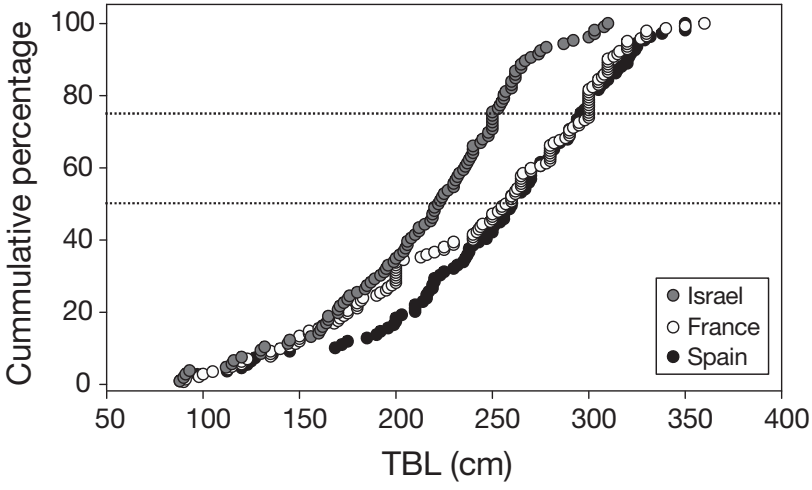

Fig. 3. Tursiops truncatus. Cumulative distribution curves of total body length (TBL) of common bottlenose dolphins stranded on the Israeli, French and Spanish Mediterranean coasts. Dotted lines: 50 and $75 \%$ of the samples

included in the above analyses, such as the upper quartiles of the stranding data from France and Spain ( $\mathrm{n}=36$ and 27, respectively). As no significant differences were found for either measure (Mann-Whitney $p=0.19$ to 1.00 ), regional comparisons were made irrespective of gender.

\section{Regional differences}

Cumulative distribution curves of the French (mostly from the Ligurian Sea), Spanish (mostly from the Balearic Sea) and Israeli TBL series are shown in Fig. 3. The curves of the 2 western populations practically overlap; in contrast, at $50 \%$ cumulative distribution the Israeli dolphins are $38 \mathrm{~cm}$ smaller, and at $75 \%$ they are $47 \mathrm{~cm}$ smaller than their western counterparts. Comparing median TBL of the upper quartiles of the 3 series (Table 3) showed that the Israeli median length was significantly shorter than both western series (KruskalWallis, $\chi^{2}=43.3, \mathrm{p}<0.001$; Mann-Whitney, $\mathrm{p}<$ 0.001 for both comparisons), with no significant difference between the 2 western series (MannWhitney, $\mathrm{p}=0.333$ ).

Cumulative distribution curves of combined Ligurian-Balearic-Alboran, Tyrrhenian, Adriatic and Israeli CBL series are shown in Fig. 4. The 3 western curves practically overlap. There were no western dolphins with CBL $<50 \mathrm{~cm}$, whereas $67 \%$ of the eastern dolphin CBLs were $<50 \mathrm{~cm}$. The mean $( \pm \mathrm{SD}) \mathrm{CBL}$ value in the Israeli population $(49.70 \pm 1.87 \mathrm{~cm})$ was significantly smaller than that of the combined western population $(52.18 \pm$ $1.47 \mathrm{~cm})$ ( $t$-test $\mathrm{p}<0.001)$ as well as each individual western subpopulation (1-way ANOVA, 


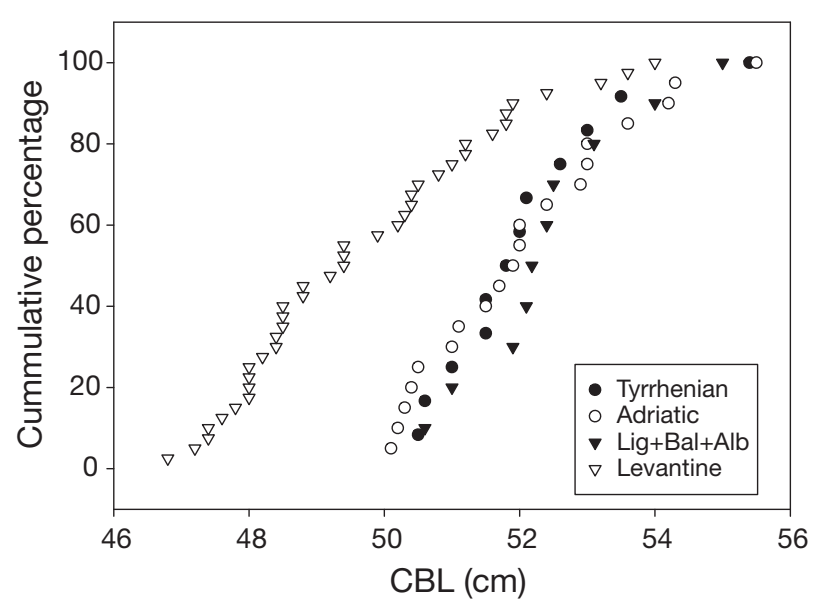

Fig. 4. Tursiops truncatus. Cumulative distribution curves of condylobasal length (CBL) by region (see Fig. 1). Lig+Bal+ Alb: Ligurian, Balearic and Alboran Seas combined

Table 4. Tursiops truncatus. Condylobasal length (CBL; mean $\pm \mathrm{SD}$ ) in Israeli and western Mediterranean subpopulations. Lig+Bal+Alb: Ligurian, Balearic and Alboran Seas combined

\begin{tabular}{|lccc|}
\hline Population & $\mathrm{N}$ & $\mathrm{CBL}(\mathrm{cm})$ & Range \\
\hline Israel & 40 & $49.7 \pm 1.88$ & $46.8-54.0$ \\
Adriatic & 19 & $52.1 \pm 1.37$ & $50.5-55.4$ \\
Tyrrhenian & 12 & $52.1 \pm 1.57$ & $50.1-55.5$ \\
Lig+Bal+Alb & 9 & $52.5 \pm 1.39$ & $50.6-55.0$ \\
\hline
\end{tabular}

$\mathrm{p}<0.001$; Tukey's test, $\mathrm{p}<0.001$ for all comparisons) (Table 4). Similar to our results for TBL, 1-way ANOVA did not reveal significant differences in CBL among western Mediterranean subpopulations residing in different seas (Tukey's test, $\mathrm{p}>0.94$ for all comparisons).

The mean $( \pm \mathrm{SD})$ CBL:TBL ratio for the Israeli population $(\mathrm{n}=14)$ was not significantly different at $0.195 \pm 0.015$ from that for the combined western Mediterranean population $(0.192 \pm 0.017)$ (2-tailed $t$ test for assumed equal variances, $\mathrm{p}=0.606$ ).

\section{DISCUSSION}

The principal finding of this study is that on account of both TBL of presumably mature specimens and skull length of specimens with presumably mature skulls, common bottlenose dolphins off the Israeli Mediterranean coast are significantly shorter that their counterparts off the coasts of western Mediterranean seas.

\section{CBL-TBL correlation}

The 2 length parameters were well correlated. Some of the scatter could be explained by cranial maturity in $\mathrm{BD}$ and other delphinids occurring earlier than physical maturity (cessation of body growth). Mead \& Potter (1990) found cranial maturity of BD to be established at a mean age of $3.5 \mathrm{yr}$, when-according to the age-length relationship which they present-the dolphins are about $25 \mathrm{~cm}$ shorter than the asymptotic length (indicating physical maturity) occurring at the mean age of $13 \mathrm{yr}$. Analysis of the Israeli samples points to a similar conclusion: skull maturation is probably achieved at the age of 3 to $4 \mathrm{yr}$, while physical maturation estimated from asymptotic body length occurs at the age of 6 and $16 \mathrm{yr}$ in females and males, respectively (D. Kerem unpubl. data). Thus, although all skulls in the present study were judged to be mature, some may have belonged to animals that were still growing. The justification of using skull length in place of whole body length for comparing sizes of the 2 (or more) populations applies as long as the ratio of the growth constants for whole body and skull are similar. Since we have no information about this ratio for our study animals, the safest approach would be to judge Levantine nanism separately by CBL of cranially mature skulls and TBL of physically mature animals. We have no information on age composition or physical maturity for the western sample and we acknowledge the uncertainties behind the comparison of stranding databases lacking such data. The age structure of the populations may vary with conservation status, with a larger representation of physically immature animals in a depleted population (Chivers 2002). Also, the age structure of strandings may vary with the cause of stranding and thus misrepresent the true population structure; for instance, incidental mortality in trawl nets which accounts for about $30 \%$ of the annual mortality of BD in Israel (Israel Marine Mammal Research \& Assistance Center [IMMRAC] unpubl. data) may disproportionately affect less experienced juveniles. However, the fact that in the top $25 \%$ of the strandings sorted by length, no animal in the Israeli subsample had a TBL $>310 \mathrm{~cm}$ while $37.8 \%$ of the French and $59.3 \%$ of the Spanish subsamples did, supported our principal finding.

\section{Sexual dimorphism}

Sexual dimorphism in adult body size has mainly been addressed in BD populations along the southeastern coast of North America. Most studies (i.e. 
Read et al. 1993, Fernandez \& Hohn 1998, McFee et al. 2010) found mature males to be $\sim 10 \mathrm{~cm}$ longer than females. The reason for the absence of any evidence for sexual dimorphism in our study may be that the sample sizes studied here were too small to reveal such a difference (a trend of males being longer than females was seen in TBL of the Israeli and Spanish, but not of the French sample group; data not shown).

\section{Regional difference}

The most notable and clear result of the present study is the significantly smaller body and skull size of BDs residing in the Levantine Basin, as represented by Israeli specimens, compared to conspecifics in western Mediterranean seas. The global, high mobility and long-distance movement of BDs (reviewed by Bearzi et al. 2011) need to be taken into account when comparing subpopulations that are not separated by physical barriers. The straight-line distance between the Sicilian Channel and the Israeli coast is $2200 \mathrm{~km}$, increasing by $1000 \mathrm{~km}$ when following closely along the North African coastline. This is within the traveling capacity of the species, as shown by 'Guliver', a member of the eastern North Atlantic offshore BD population: based on satellite tracking over a period of $47 \mathrm{~d}$ following post-stranding release, he covered a distance of $4200 \mathrm{~km}$ (Wells et al. 1999). The traveling range of BD in the Mediterranean has only been followed through resightings of familiar or photo-identified individuals (Bearzi et al. 2011). The longest distance was recorded for the solitary but sociable 'Dolphy', roaming the coasts of France and Spain over a distance of $400 \mathrm{~km}$ (Lockyer \& Müller 2003). Thus, migration between the eastern and western Mediterranean Seas appears to be rare. However, while the Levantine subpopulation of BDs is genetically distinct, there is also genetic evidence of migration from the western Mediterranean into this eastern subpopulation (Natoli et al. 2005). This evidence of occasional migration and the possibility that the Levantine sample contains individuals of a longer, offshore morph (Mead \& Potter 1995) could well explain part of the size overlap observed in our study (Tables $3 \& 4$ ).

The fact that mean TBL of BD from Israel is $16 \%$ lower than the western Mediterranean mean, while mean skull length is only $5 \%$ lower, may mean that early growth is similar in the 2 populations and that most of the difference occurs after the animals reach $4 \mathrm{yr}$ of age. This is in line with the overlap of the lower parts of the cumulative distribution length curves (Fig. 3). Previous work on length of Mediterranean $\mathrm{BD}$ is sparse and only concerns the Adriatic Sea. In a sample of 20 dolphins from the Adriatic Sea, Pribanic et al. (2000) report that TBL of 3 females and 2 males ranged from 285 to $290 \mathrm{~cm}$ and that the combined length asymptote for both sexes was at $280 \mathrm{~cm}$. Butti et al. (2007), examining a sample from the same region, reported females being 272 to $277 \mathrm{~cm}$ long at the age of 6 to $10 \mathrm{yr}$ and males 270 to $305 \mathrm{~cm}$ long at the age of $\geq 10 \mathrm{yr}$. Of $16 \mathrm{BD}$ that stranded on the shore of the province of Brindisi, southern Adriatic, the 6 largest animals measured 271, 290, 290, 298, 300 and $318 \mathrm{~cm}$ (Pino d'Astore et al. 2008). Of the 13 specimens from the Italian Adriatic coast for which TBL was known in the present study, the 6 largest animals measured 280,285,290,295, 311 and 316. The 6 largest animals in the entire Israeli stranding record measured 287, 293, 303, 303, 308 and $310 \mathrm{~cm}$. Thus, while strict comparison is not warranted, it would seem that the Adriatic BDs are closer in overall size to the Israeli BDs than to conspecifics in basins further west. Since the skulls from Adriatic Sea BDs examined for this study were comparable in size to those of Mediterranean subpopulations further to the west, the question of body and skull size of BD in the Central Mediterranean remains unanswered.

Regarding the Black Sea, Barabash-Nikiforov (1940), Tomilin (1957) and Viaud-Martinez et al. (2008) suggested a smaller body size of the Black Sea BDs relative to Mediterranean animals. While recently recorded dolphins are indeed remarkably small (Viaud-Martinez et al. 2008), the dolphins inspected in the 1930s were considerably longer: Barabash-Nikiforov (1940) measured 52 specimens that were 270 to $310 \mathrm{~cm}$ long, thus matching the size range of Mediterranean BDs observed nowadays.

\section{Extent of dwarfism}

Does the size difference we found qualify for 'dwarfism' terminology? Table 5 lists mean values for TBL and CBL in selected cetacean species with known dwarf and pigmy morphs (blue whale, minke whale, killer whale and spinner dolphin) as well as for dolphin species (BD included) for which segregation by size, mostly of coastal and offshore populations, has been demonstrated. The latter also include the 2 species of spotted dolphins, the pantropical spotted dolphin Stenella attenuata, with the smaller (offshore) $S$. attenuata attenuata and the larger (coastal) S. attenuata graffmani, and the Atlantic 
Table 5. Extent of dwarfism in cetaceans and fish. CBL: condylobasal length $(\mathrm{cm})$, TBL: total body length (cm), M: male, F: female, Med: Mediterranean. Parentheses: sample size. \% Regular: diminutive length as a percentage of regular length. Note that in spotted dolphins, the offshore populations are as a rule smaller than the coastal ones, and in common bottlenose dolphins (BD) it is the other way around; in both cases, neither morph is regarded as the 'regular' one

\begin{tabular}{|c|c|c|c|c|c|c|c|}
\hline \multirow[t]{2}{*}{ Species } & \multicolumn{2}{|c|}{$\%$ Regular } & \multicolumn{2}{|c|}{ Regular } & \multicolumn{2}{|c|}{ Diminutive } & \multirow[t]{2}{*}{ Source } \\
\hline & CBL & TBL & $\mathrm{CBL}$ & TBL & CBL & TBL & \\
\hline Blue whale $(\mathrm{F})$ & & 85 & & $2550(111)$ & & $2170(7)$ & Gilpatrick \& Perryman (2008) \\
\hline Minke whale (M) & & 82.5 & & 800 & - & 660 & Jefferson et al. (2008) \\
\hline Minke whale $(\mathrm{F})$ & & 81.4 & & 860 & - & 700 & \\
\hline Killer whale (M) & & 70 & & 800 & & $560(65)$ & Pitman et al. (2007) \\
\hline Killer whale (F) & & 77.6 & & 670 & & $520(33)$ & \\
\hline Spinner dolphin (M) & 81.5 & 77.5 & $43.6(22)$ & 187 & $35.4(27)$ & $145(8)$ & Perrin et al. (1999) \\
\hline Pantropical spotted dolphin (M) & 90.6 & 88 & $43.7(31)$ & $227(32)$ & $39.6(575)$ & $201(253)$ & Perrin et al. (1987) \\
\hline Pantropical spotted dolphin (F) & & 89.5 & & $209(70)$ & & $187(555)$ & \\
\hline Atlantic spotted dolphin (F) & 88.1 & 86 & $42.8(62)$ & $215(15)$ & $37.7(8)$ & 185 (few) & Perrin et al. (1987) \\
\hline BD Eastern North Atlantic & 91.4 & 87.7 & $51.1(24)$ & $285(23)$ & $46.7(60)$ & $250(62)$ & Mead \& Potter (1995) \\
\hline BD East Med and West Med & 95.2 & 86.7 & $52.2(40)$ & $315(54)$ & $49.7(40)$ & $273(26)$ & This study \\
\hline Red mullet M & & 75.6 & & $19.3(4)$ & & $14.6(8)$ & Sonin et al. (2007) \\
\hline Red mullet F & & 78.2 & & $20.2(8)$ & & $15.8(7)$ & \\
\hline
\end{tabular}

spotted dolphin $S$. frontalis, with the smallest representatives inhabiting waters around oceanic Islands (Azores) and the high seas of the western North Atlantic, and the largest residing along the continental shelf of North America. With the exception of the dwarf killer whale and dwarf spinner dolphin, in which the extent of dwarfism is more pronounced, the $\%$ dimunition that we describe in Mediterranean $\mathrm{BD}$ is well within the range expressed by other species (columns 6 \& 7 in Table 5). Still, the immense global size range of BDs accommodates adults with masses differing by a factor of 4 , so using 'dwarf' terminology may only be appropriate regionally and concerning the same ecotype (coastal or offshore). Also included in Table 5 are the data in support of Levantine nanism in the red mullet (Sonin et al. 2007), in which dwarfism is similar to that expressed by the killer whale and spinner dolphin dwarf forms.

\section{Head-to-body proportions}

The CBL:TBL ratio of 0.192 for the western sample which mainly represented Adriatic animals was not significantly different from that of the Levantine sample of 0.195. Viaud-Martinez et al. (2008), who investigated 13 specimens from the Ligurian Sea for which both TBL and CBL were known, also reported a ratio of 0.192 , so it seems safe to say that head-tobody proportions are maintained across the Mediterranean. This is in contrast to the Black Sea BD, whose CBL:TBL ratio was significantly larger, at 0.206 (Viaud-Martinez et al. 2008).

\section{Environmental factors and Levantine nanism}

Differences observed might be explained by one or more of the 3 environmental parameters allegedly responsible for the Levantine nanism phenomenon (Por \& Dimentman 2006): high salinity, high temperature and low primary productivity. All 3 are known to characterize the Levantine Basin (Herut et al. 2000, Turley et al. 2000, Bricaud et al. 2002). These explanatory parameters were originally proposed for invertebrates and fish (Por \& Dimenman 2006), but their relevance for mammalian homeotherms should be evaluated. In fish, these 3 parameters are suspected of causing early sexual maturation, so that energy is invested in reproduction at the expense of growth (Jobling 1996). Early sexual maturation and early growth cessation could also apply to dolphins. However, age at physical maturation could be maintained and the smaller adult size could come about by slower initial growth and/or a more pronounced growth retardation as the individual nears asymptotic final size (Laird 1966). This point can only be clarified by comparing length by age curves of the relevant subpopulations.

Ferraris et al. (1986) suggested that reduced growth rates in fish under conditions of high salinity were related to the high energetic costs of osmoregulation, which would also apply to marine homeotherms, though possibly less so to piscivores. With everything else being equal, any increase in maintenance energetic demands would promote smaller size (see below), but since the salinity cline in the Mediterranean follows the same general east-west direction as that 
of mean water column temperature and productivity, isolating its effect would be difficult. Direct intraspecific effect of salinity on body size is unknown for marine mammals. Were it important-since surface salinity in the Mediterranean Sea is one of the highest in the world (Antonov et al. 2006) - one would expect various Mediterranean cetacean species to have the smallest body size globally, but this is not the case. Also, relatively small body size is observed in all 3 resident Black Sea cetacean species-namely BD (Barabash-Nikiforov 1960), short-beaked common dolphin Delphinus delphis (Kleinenberg 1956) and harbor porpoise Phocoena phocoena (Gol'din 2004) which presumably entered the Black Sea from the Mediterranean and Sea of Marmara ca. 10000 yr ago (Aksu et al. 1999; see also Viaud-Martinez et al. 2008) and adapted to its very low-salinity waters.

Surface temperature in the Mediterranean does not present as clear an east-west gradient as that seen in salinity (Brasseur et al. 1996). The influence of water temperature on the distribution of marine mammals would be expected to follow Bergmann's rule (Bergmann 1847) for species within higher taxa, and its modification (Rensch 1938, Mayr 1956) for populations within species, which states that lower and warmer latitudes will tend to host animals with lower body mass. Searcy (1980) has presented an energy balance model in which selection is considered to maximize the difference between energy intake or gain per unit of time and maintenance energy costs per unit of time, scaled to body size. The model, that not only considers thermoregulatory constraints, predicts an increase in optimum body size as temperature decreases, providing an energetic basis and adaptive significance for the rule. Very few studies tested the validity of this rule in small cetaceans. Ross \& Cockcroft (1990) found that the increase of surface water temperature at lower latitudes generates a smaller body size and skull size in the IndoPacific bottlenose dolphin Tursiops aduncus. Striped dolphins Stenella coeruleoalba off the French Mediterranean coast grow to smaller final size than conspecifics off the French Atlantic coast (Di-Meglio et al. 1996), and populations of the finless porpoise Neophocaena phocaenoides tend to have larger skulls in temperate than in tropical reaches of the species' range (Jefferson 2002). On the other hand, Bergmann's rule does not hold for the harbor porpoise (Gol'din 2004) or for Black Sea cetaceans in general, which tend towards dwarfism despite the relatively cold environment (Tomilin 1957, Perrin 1984). Also, if temperature and thermoregulation were important, the western BD subpopulation would possess relatively smaller flippers, in adherence to Allen's rule (Allen 1877).

Sergeant \& Brodie (1969) suggested that size variation in beluga whales Delphinapterus leucas was directly correlated with primary production in the habitat. Brodie (1975) later claimed that intraspecific size variation in cetaceans with a restricted feeding period may largely depend on lipid storage requirements, but such a consideration may not apply to BDs. Primary productivity of the Levantine Basin is extremely low (Krom et al. 2004) even in comparison with the western Mediterranean (Antoine et al. 1995); in addition, primary production is very efficiently utilized in the northwest Mediterranean, increasing fish biomass (Estrada 1996). Differences in primary productivity and subsequently resource availability could explain some of the body size variation in BDs on a worldwide scale. For example, the Gulf of Mexico with the adjoining Atlantic waters is an oligotrophic basin with primary production generally comparable with that of the Mediterranean (Pennock et al. 1999), and BDs in this region generally do not exceed the size of their Mediterranean conspecifics (McFee et al. 2010), while BDs in the eutrophic waters of the northwest Pacific or northeast Atlantic are remarkably large (Wells \& Scott 2009). Thus, food resource availability can stand as a working hypothesis for BD nanism in the Levantine Basin. Primary productivity in the Mediterranean decreases with distance from the Gibraltar Strait but also from the Adriatic and Aegean Seas, which are productivity hotspots relative to their west-east position (Antoine et al. 1995). This would predict relatively large BDs in the Adriatic. It should however be remembered that high primary productivity will support a higher mass of top predators only when no external intervention is present. Anthropogenic competition for and overexploitation of dolphin prey would introduce new selection pressures which could limit the number of optimally sized individuals and/or have individuals reach less than optimum adult sizes. The second effect has been described in artiodactyls, where long enough periods of food depletion, lasting through pregnancy and lactation, will lead to small adult size as affected calves mature (Festa-Bianchet et al. 2000).

Another anthropogenic impact with potential local effect on body size of marine mammals is chemical contamination. Growth stunting may be caused by the general stress of a high contaminant burden and specifically by thyroid disruptors (Wade et al. 2002), even though this has not been directly demonstrated in marine mammals. A correlation between organo- 
pollutant levels and degree of thyroid gland fibrosis has been demonstrated in eastern North Atlantic harbor porpoises (summarized in Schnitzler et al. 2009). Israeli BDs, however, demonstrate total blubber PCB values an order of magnitude lower than those in animals in the western Mediterranean (Shoham-Frider et al. 2009), and while possessing relatively high tissue cadmium loads (presumably of natural origin from Sahara sands) (Roditi-Elasar et al. 2003), cadmium was shown to be negatively correlated to thyroid gland fibrosis in harbor porpoises (Schnitzler et al. 2009).

Our research joins a list of studies in supporting the Levantine nanism phenomenon but does so for the first time in a marine mammal. The relative contribution to Levantine nanism of the various environmental parameters (natural and anthropogenic) is hard to estimate but provides direction for further research. Lastly, it should be stressed that the concept of Levantine nanism may well be the expression of boundary effects of a cross-Mediterranean east-west cline in body size. It is highly conceivable that when other Mediterranean subpopulations of marine organisms to which this concept has been applied (including $\mathrm{BDs}$ ) are inspected, Levantine nanism would have to be reevaluated or at least reassessed with a wider perspective.

Acknowledgements. We express sincere gratitude to all listed institutions for allowing access to their collections. Special thanks are due to T. Shariv for her help at the Tel Aviv University Museum, to E. Garcia Franquesa (Zoological Museum, Barcelona), to J.A. Raga (Evolutionary Biology Department, University of Valencia), to R. Carlini (Museo Civico di Zoologia, Rome), to P. Agnelli (La Specola Zoological Museum, University of Florence), to D. Scaravelli (CdL Aquacoltura e Ittiopatologia, Facoltà di Veterinaria, University of Bologna) and to M. Podesta (Museum of Natural History, Milan). We thank all dedicated IMMRAC stranding network volunteers for carrying out the messy work leading to a skeletal collection. The MEDACES-Mediterranean Database of Cetacean Strandings, Centre de Recherche sur les Mammifères Marins and Groupe d'Étude des Cétacés de Méditerranée-France provided particularly useful data for this study. We thank S. Meiri for his advice and comments, and P. Goldstein for advice on the statistics. This study was partly financed by a research grant from the Sir Maurice \& Lady Irene Hatter Fund for Maritime Studies.

\section{LITERATURE CITED}

Aksu AE, Hiscott RN, Yasar D (1999) Oscillating quaternary water levels of the Marmara Sea and vigorous outflow into the Aegean Sea from the Marmara Sea-Black Sea drainage corridor. Mar Geol 153:275-302

Allen JA (1877) The influence of physical conditions in the genesis of species. Radical Rev 1:108-140
Antoine D, Morel A, André JM (1995) Algal pigment distribution and primary production in the Eastern Mediterranean as derived from Coastal Zone Color Scanner observations. J Geophys Res 100:16193-16209

Antonov JI, Locarnini RA, Boyer TP, Mishonov AV, Garcia HE (2006) World ocean atlas 2005, Vol 2: salinity. NOAA atlas NESDIS 62. US Government Printing Office, Washington, DC

Barabash-Nikiforov II (1940) Cetacean fauna of the Black Sea, its origin and composition. State University of Voronezh, Voronezh

Barabash-Nikiforov II (1960) Dimension and coloration of Tursiops truncatus as a criterion of their subspecies differentiation. Nauchnye Doki Vyss Shkoly Biol Nauki 1: 35-42

Bearzi G, Politi E, Notarbartolo di Sciara G (1999) Diurnal behavior of free-ranging bottlenose dolphins in the Kvarneric (northern Adriatic Sea). Mar Mamm Sci 15: 1065-1097

> Bearzi G, Politi E, Agazzi S, Azzellino A (2006) Prey depletion caused by overfishing and the decline of marine megafauna in eastern Ionian Sea coastal waters (central Mediterranean). Biol Conserv 127:373-382

Bearzi G, Bonizzoni S, Gonzalvo J (2011) Mid-distance movements of common bottlenose dolphins in the coastal waters of Greece. J Ethol 29:369-374

Bergmann C (1847) Ueber die Verhältnisse der Wärmeökonomie der Thiere zu ihrer Grösse. Goett Stud 3:595-708

Berzin AA, Vladimirov VL (1983) New species of killer whale (Cetacea, Delphinidae) from Antarctic waters. Zool Zh 62:287-295

Best PB (1985) External characters of southern minke whales and the existence of a diminutive form. Sci Rep Whales Res Inst Tokyo 36:1-33

> Brasseur P, Beckers JM, Brankart JM, Schoenauen R (1996) Seasonal temperature and salinity fields in the Mediterranean Sea: climatological analyses of a historical data set. Deep-Sea Res I 43:159-192

Bricaud A, Bosc E, Antoine D (2002) Algal biomass and sea surface temperature in the Mediterranean basin: intercomparison of data from various satellite sensors, and implications for primary production estimates. Remote Sens Environ 81:163-178

Brodie PF (1975) Cetacean energetics, an overview of intraspecific size variation. Ecology 56:152-161

Butti C, Corain L, Cozzi B, Podesta M, Pirone A, Affronte M, Zotti A (2007) Age estimation in the Mediterranean bottlenose dolphin Tursiops truncatus (Montagu 1821) by bone density of the thoracic limb. J Anat 211:639-646

Chivers SJ (2002) Age structure of female eastern spinner dolphins (Stenella longirostris orientalis) incidentally killed in the eastern tropical pacific tuna purse-seine fishery. Admin rep LJ-02-11, National Marine Fisheries Service, NOAA, La Jolla, CA

Dailey MD, Perrin WF (1973) Helminth parasites of porpoises of the genus Stenella in the eastern tropical pacific, with descriptions of two new species: Mastigonema stenellae gen. et sp. n. (Nematoda: Spiruroidea) and Zalophotrema pacificum sp. n. (Trematoda: Digenea). Fish Bull 71:455-471

Di-Meglio N, Romero-Alvarez R, Collet A (1996) Growth comparison in striped dolphins, Stenella coeruleoalba, from the Atlantic and Mediterranean coasts of France. Aquat Mamm 22:11-19

Dugdale RC, Wilkerson FP (1988) Nutrient sources and pri- 
mary production in the Eastern Mediterranean. Oceanol Acta 9(Special):179-184

Edelist D, Sonin O, Golani D, Rilov G, Spanier E (2011) Spatiotemporal patterns of catch and discards of the Israeli Mediterranean trawl fishery in the early 1990s: ecological and conservation perspectives. Sci Mar 75:641-652

Ellison GTH, Taylor PJ, Nix HA, Bronner GN, McMahon JP (1993) Climatic adaptation of body size among pouched mice (Saccostomus campestris, Cricetidae) in the southern African subregion. Global Ecol Biogeogr Lett 3: 41-47

Estrada M (1996) Primary production in the northwestern Mediterranean. Sci Mar 60:55-64

Fernandez F, Hohn AA (1998) Age, growth and calving season of bottlenose dolphins, Tursiops truncatus, off coastal Texas. Fish Bull 96:357-365

Ferraris RP, Catacutan MR, Mabelin RL, Jazul AP (1986) Digestibility in milkfish, Chanos chanos (Forsskal): effects of protein source, fish size and salinity. Aquaculture 59:93-105

Festa-Bianchet M, Jorgenson JT, Réale D (2000) Early development, adult mass and reproductive success of bighorn sheep. Behav Ecol 11:633-639

Gilpatrick JW, Perryman WL (2008) Geographic variation in external morphology of North Pacific and Southern Hemisphere blue whales (Balaenoptera musculus). J Cetacean Res Manag 10:9-21

Gol'din PE (2004) Growth and body size of the harbour porpoise, Phocoena phocoena (Cetacea, Phocoenidae), in the Sea of Azov and the Black Sea. Vestn Zool 38:59-73

Hersh SL, Duffield DA (1990) Distinction between Northwest Atlantic offshore and coastal bottlenose dolphin based on hemoglobin profile and morphometry. In: Leatherwood S, Reeves RR (eds) The bottlenose dolphin. Academic Press, San Diego, CA, p 129-139

Herut B, Almogi-Labin A, Jannink NT, Gertman I (2000) The seasonal dynamics of nutrient and chlorophyll a concentrations on the SE Mediterranean shelf-slope. Oceanol Acta 23:771-782

Jefferson TA (2002) Preliminary analysis of geographic variation in cranial morphometrics of the finless porpoise (Neophocaena phocaenoides). Raffles Bull Zool Suppl 10:3-14

Jefferson TA, Webber MA, Pitman RL (2008) Common minke whale - Balaenoptera acutorostrata. In: Marine mammals of the world: a comprehensive guide to their identification. Academic Press, London, p 59-62

Jobling M (1996) Environmental biology of fishes. Chapman \& Hall, London

> Jones M (1997) Character displacement in Australian dasyurid carnivores: size relationships and prey size patterns. Ecology 78:2569-2587

Kemper CM (2004) Osteological variation and taxonomic affinities of bottlenose dolphin Tursiops spp. from South Australia. Aust J Zool 52:29-48

Kleinenberg SE (1956) Mammals of the Black Sea and the Sea of Azov: an experience of biological and exploitation study. Izdatelstvo AN SSSR, Moscow (in Russian)

Krom MD, Herut B, Mantoura RFC (2004) Nutrient budget for the Eastern Mediterranean: implications for P limitation. Limnol Oceanogr 49:1582-1592

Kurihara N, Oda S (2006) Cranial variation and taxonomic revision of bottlenose dolphin (Tursiops spp.) from Japanese waters. Aquat Mamm 32:289-300

Laird AK (1966) Postnatal growth of birds and mammals.
Growth 30:349-362

Laubier L (1966) Sur quelques Annélides de la région de Beyrouth. Am Univ Beirut Misc Pap Nat Sci 5:9-22

Leatherwood S, Reeves RR (1983) The Sierra club handbook of whales and dolphins. Sierra Club Books, San Francisco, CA

Leatherwood S, Reeves RR (eds) (1990) The bottlenose dolphin. Academic Press, San Diego, CA

Levi C (1957) Spongiaires des côtes d'Israel. Bull Res Counc Isr 6:201-212

Liebig PM, Ta-Shana AT, Flessa KW (2003) Bones on the beach: marine mammal taphonomy of the Colorado Delta, Mexico. Palaios 18:168-175

Lockyer C, Müller M (2003) Solitary, yet sociable. In: Frohoff T, Peterson B (eds) Between species: celebrating the dolphin-human bond. Sierra Club Books, San Francisco, CA, p 138-150

Mayr E (1956) Geographical character gradients and climatic adaptation. Evolution 10:105-108

> McFee WE, Schwacke JH, Stolen MK, Mullin KD, Schwacke LH (2010) Investigation of growth phases for bottlenose dolphins using a Bayesian modeling approach. Mar Mamm Sci 26:67-85

Mead JG, Potter CW (1990) Natural history of bottlenose dolphin along the Central Atlantic coast of the United States. In: Leatherwood S, Reeves RR (eds) The bottlenose dolphin. Academic Press, San Diego, CA, p 165-195

Mead JG, Potter CW (1995) Recognizing two populations of the bottlenose dolphin (Tursiops truncatus) off the Atlantic coast of North America: morphologic and ecologic considerations. IBI Rep 5:31-44

Meiri S, Dayan T, Simberloff D (2004) Body size of insular carnivores: little support for the island rule. Am Nat 163: 469-479

Montagu G (1821) Description of a species of Delphinus, which appears to be new. Mem Wernerian Nat Hist Soc 3:75-82

Natoli A, Birkun A, Aguilar A, Lopez A, Hoelzel AR (2005) Habitat structure and dispersal of male and female bottlenose dolphins (Tursiops truncatus). Proc Biol Sci 272: 1217-1226

Norris SK (1961) Standardized methods for measuring and recording data on the smaller Cetaceans. J Mammal 42: 471-476

Pennock JR, Boyer JN, Herrera-Silveira JA, Iverson RL, Whitledge TE, Mortazavi B, Comin FA (1999) Nutrient behavior and phytoplankton production in Gulf of Mexico estuaries. In: Bianchi TS, Pennock JR, Twilley RR (eds) Biogeochemistry of Gulf of Mexico estuaries. John Wiley, New York, NY, p 109-162

Perrin WF (1984) Patterns of geographical variation in small cetaceans. Acta Zool Fenn 172:137-140

Perrin WF, Heyning JE (1993) Rostral fusion as a criterion of cranial maturity in the common dolphin, Delphinus delphis. Mar Mamm Sci 9:195-197

Perrin WF, Mitchell ED, Mead JG, Caldwell DK, Caldwell MC, Van Bree PJH, Dawbin WH (1987) Revision of the spotted dolphins, Stenella spp. Mar Mamm Sci 3:99-170

Perrin WF, Dolar MLL, Robineau D (1999) Spinner dolphins (Stenella longirostris) of the western Pacific and Southeast Asia: pelagic and shallow-water forms. Mar Mamm Sci 15:1029-1053

Pino d'Astore P, Bearzi G, Bonizzoni S (2008) Cetacean strandings in the province of Brindisi (Italy, southern Adriatic Sea). Ann Ser Hist Nat 18:29-38 
Pitman RL, Perryman WL, LeRoi D, Eilers E (2007) A dwarf form of killer whale in Antarctica. J Mammal 88:43-48

Por DF (1989) The legacy of Tethys. Kluwer Academic Publishers, Dordrecht, p 41-64

Por DF, Dimentman C (2006) Mare nostrum. Neogene and anthropic natural history of the Mediterranean basin, with emphasis on the Levant. Pensoft, Sofia

Pribanic S, Miokovic D, Kovacic D (2000) Preliminary growth rate and body lengths of the bottlenose dolphin Tursiop truncatus (Montagu 1821) from the Adriatic Sea. Natura Croat 9:179-188

Quin DG, Smith AP, Norton TW (1996) Ecogeographic variation in size and sexual dimorphism in sugar gliders and squirrel gliders (Marsupialia: Petauridae). Aust J Zool 44: 19-45

Read AJ, Wells RS, Hohn AA, Scott MD (1993) Patterns of growth in wild bottlenose dolphins, Tursiops truncatus. J Zool (Lond) 231:107-123

Rensch B (1938) Some problems of geographical variation and species formation. Proc Linn Soc Lond 150:275-285

Rice DW (1998) Marine mammals of the world: systematics and distribution. Special Publication No. 4, Society for Marine Mammalogy, Lawrence, KS

Roditi-Elasar M, Kerem D, Hornung H, Kress N, ShohamFrider E, Goffman O, Spanier E (2003) Heavy metal levels in bottlenose and striped dolphins off the Mediterranean coast of Israel. Mar Pollut Bull 46:503-512

Ross GJB, Cockcroft VG (1990) Comments on Australian bottlenose dolphins and the taxonomic status of Tursiops aduncus (Ehrenberg 1832). In: Leatherwood S, Reeves RR (eds) The bottlenose dolphin. Academic Press, San Diego, CA, p 101-128

Schnitzler JG, Siebert U, Jepson PD, Beineke A, Jauniaux T, Bouquegneau JM, Das K (2009) Harbor porpoise thyroids: histologic investigations and potential interactions with environmental factors. J Wildl Dis 44:888-901

Scott MD, Wells RS, Irvine AB (1990) A long-term study of bottlenose dolphins on the west coast of Florida. In: Leatherwood S, Reeves RR (eds) The bottlenose dolphin. Academic Press, San Diego, CA, p 235-244

Searcy WA (1980) Optimum body sizes at different ambient temperatures: an energetic explanation of Bergmann's rule. J Theor Biol 83:579-593

Sergeant DE, Brodie P (1969) Body size in white whales Delphinapterus leucas. J Fish Res Board Can 26:2561-2580

Shoham-Frider E, Kress N, Wynne D, Scheinin A, RoditiElasar M, Kerem D (2009) Persistent organochlorine pol-

Editorial responsibility: Per Palsbøll,

Stockholm, Sweden lutants and heavy metals in tissues of common bottlenose dolphin (Tursiops truncatus) from the Levantine Basin of the Eastern Mediterranean. Chemosphere 77 : 621-627

Sonin O, Spanier E, Levi D, Patti B, Rizzo P, Andreoli MG (2007) Nanism (dwarfism) in fish: a comparison between red mullets Mullus barbatus from the southeastern and the central Mediterranean. Mar Ecol Prog Ser 343: 221-228

Stephen AC (1958) The Sipunculids of the Bay of Haifa and neighbourhood. Bull Res Counc Isr 7B:129-136

Tomilin AG (1957) Mammals of USSR and adjoining countries, Vol IX. Cetaceans. Izdatelstvo AN SSSR, Moscow (in Russian)

Tortonese E (1960) General remarks on the Mediterranean deep-sea fishes. Bull Inst Oceanogr (Monaco) 1167:1-14

Turley CM, Bianchi M, Christaki U, Conan P and others (2000) Relationship between primary producers and bacteria in an oligotrophic sea - the Mediterranean and biogeochemical implications. Mar Ecol Prog Ser 193:11-18

Turner JP, Worthy GAJ (2003) Skull morphometry of bottlenose dolphin (Tursiops truncatus) from the Gulf of Mexico. J Mammal 84:665-672

Viaud-Martinez KA, Brownell RL Jr, Komnenou A, Bohonak AJ (2008) Genetic isolation and morphological divergence of Black Sea bottlenose dolphins. Biol Conserv 141:1600-1611

> Wade MG, Parent S, Finnson KW, Foster W and others (2002) Thyroid toxicity due to subchronic exposure to a complex mixture of 16 organochlorines, lead, and cadmium. Toxicol Sci 67:207-218

Walker WA (1981) Geographical variation in morphology and biology of bottlenose dolphins (Tursiops) in the eastern north Pacific. Admin rep LJ-81-03C. National Marine Fisheries Service, La Jolla, CA

Wells RS, Scott M D (2009) Common bottlenose dolphin (Tursiops truncatus). In: Perrin WF, Würsig B, Thewissen JGM (eds) Encyclopedia of marine mammals, 2nd edn. Elsevier, San Diego, CA, p 249-255

> Wells RS, Rhinehart HL, Cunningham P, Whaley J, Baran M, Koberna C, Costa DP (1999) Long distance offshore movements of bottlenose dolphins. Mar Mamm Sci 15: 1098-1114

Yacobi YZ, Zohary T, Kress N, Hecht A and others (1995) Chlorophyll distribution throughout the southeastern Mediterranean in relation to the physical structure of the water mass. J Mar Syst 6:179-190

Submitted: April 4, 2011; Accepted: July 1, 2011

Proofs received from author(s): September 13, 2011 